\title{
繰返し軟化を示す金属の弾塑性変形挙動の高精度予測への 下負荷面モデルの拡張
}

\author{
樋口 良太 ${ }^{* 1}$, 岡村 一男 ${ }^{* 2}$, 太田 文雄 ${ }^{* 3}$ ，橋口 公一 ${ }^{* 4}$ \\ Extension of subloading surface model for accurate prediction of \\ elastoplastic deformation behavior of metals with cyclic softening
}

\author{
Ryota HIGUCHI ${ }^{* 1}$, Kazuo OKAMURA, Fumio OHTA and Koichi HASHIGUCHI \\ ${ }^{* 1}$ Nippon Steel \& Sumitomo Metal Corporation \\ Fuso-Cho 1-8, Amagasaki, Hyogo, 660-0891, Japan
}

Received 2 December 2013

\begin{abstract}
The subloading surface model has been formulated and applied to the prediction of cyclic loading behavior of metals. However, the existing formulation of this model is limited to metals exhibiting only the cyclic hardening. In the present paper, the material functions prescribing the elastic-plastic transition are extended so as to describe the inverse and reloading behavior and the strain accumulation in cyclic loading more accurately for metals exhibiting not only the cyclic hardening but also the cyclic softening behavior. The experiments on the uniaxial cyclic loading of the seamless steel pipe P110 which exhibits the cyclic softening are performed for the mechanical ratcheting and the constant strain amplitudes. The simulations to the test data are performed by using the same set of material constants. Then, the validity of the extended model for the description of cyclic loading behavior of the seamless steel pipe is verified by comparisons with the test data.
\end{abstract}

Key Words : Constitutive equation, Elastoplasticity, Subloading surface model, Cyclic hardening/softening, Seamless steel pipe

\section{1. 緒言}

繰返し負荷を受ける諸機械構造物の力学設計に種々の弾塑性構成式が用いられている。これらは，純粋弾性域 を囲む降伏面の移動，つまり “移動硬化”の概念に基づくモデルと，常に現応力点を通って降伏面に相似な面の 拡大・縮小に基づく“下負荷面”の概念(Hashiguchi, 1980, 1989)に基づくモデルに分類される. 前者の移動硬化の 概念に基づくものとして，多面モデル(Morz, 1967; Iwan, 1967)，二面モデル(Dafalias and Popov, 1975; Krieg, 1975; Yoshida and Uemori, 2002a, 2002b, 2003)および非線形移動硬化モデル(Chaboche, et al., 1979; Ohno and Wang, 1993a, 1993b)が提案され，金属材料の塑性変形挙動の解析に広く採用されている。これらには，1）実在材料に見られ る滑らかな応力ーひずみ曲線が描かれない，2）純粋弾性域を囲む降伏面が最高応力状態に達する，3）負荷基 準において，ひずみ速度または応力速度の方向についての判定に加えて，応力が降伏面上に有るか否かの判定が 必要である，4）応力を降伏面に引き戻す計算プログラム（リターンマッピングを含む）を要する，5）降伏面 の接線方向の応力速度による非弾性ひずみ速度の導入が不可能である等の問題点が見られる．他方，後者の下負 荷面の概念に基づくモデルは，応力が降伏面に近づくにつれて塑性ひずみ速度が発達する極めて自然な仮定に基 づくので，これらの諸問題を含まない基本構造を有している.

下負荷面モデル(Hashiguchi，1980)は，降伏面に対する下負荷面の相似中心が塑性ひずみ速度とともに移動する ように拡張され(Hashiguchi，1989)，さらに再負荷曲線が先行負荷曲線に速やかに復帰するように改善されている

* 論文 No. 13-00840 [DOI: 10.1299/transjsme.2014smm0082]

${ }^{* 1}$ 正員，新日鐵住金(株）技術開発本部（广 660-0891 兵庫県尼崎市扶桑町 1-8）

$*_{2}$ 正員，フェロー，新日鐵住金(株) 技術開発本部

*3 新日鐵住金(株) 和歌山製鐵所（广 $640-8555$ 和歌山県和歌山市湊 1850)

${ }^{* 4}$ 正員，九州大学名誉教授，大阪大学接合科学研究所（干567-0047 大阪府茨木市美穂ヶ丘 11-1）

E-mail: higuchi.f5g.ryohta@jp.nssmc.com

[DOI: 10.1299/transjsme.2014smm0082] 
(Hashiguchi, 2013)。それにより，種々の単調・繰返し単軸負荷や円形ひずみ負荷等の実測值をシミュレーション できることが実証されている(Hashiguchi et. al., 2012)。これらは，個々に，単一の試験結果をシミュレーションし たものであるとともに，繰返し硬化を対象としたものである.

本報では，繰返し硬化のみならず繰返し軟化を示す金属を対象に，逆負荷・再負荷特性および繰返し負荷にお けるひずみの集積を高精度で表現し得るように，下負荷面モデルに含まれる弾一塑性遷移に関する物質関数の拡 張を行う．繰返し軟化を示すシームレス鋼管材料を対象に，単軸負荷条件において，定ひずみ振幅繰返し試験お よび応力片振り試験，つまり力学的ラチェット試験を実施し，本試験結果について報告する．繰返し軟化を表現 し得るように拡張された下負荷面構成式により, 同一の材料パラメータ值の組を用いて, これらの全試験結果を 高精度でシミュレーションし得ることを実証する.

\section{2. 下負荷面モデルの基本式}

\section{$2 \cdot 1$ 下負荷面の概念に基づく構成式}

速度勾配の対称部分としてのひずみ速度 $\mathbf{d}$ は, 弾性ひずみ速度 $\mathbf{d}^{e}$ と塑性ひずみ速度 $\mathbf{d}^{p}$ に加算分解されると仮 定する．弾性ひずみ速度は，亜弾性構成式に基づく次式で与えられるとする.

$$
\mathbf{d}^{e}=\mathbf{E}^{-1}: \stackrel{\text { 厂 }}{ }
$$

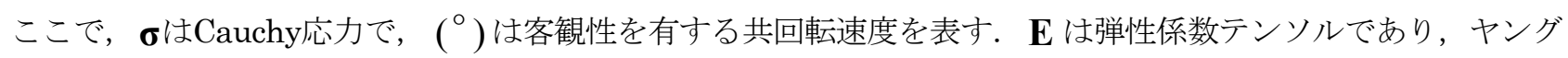
率 $E$ おびポアソン比 $v$ 用いて次式のHook形で与えられる.

$$
\left.\begin{array}{rl}
E_{i j k l} & =\frac{v E}{(1+v)(1-2 v)} \delta_{i j} \delta_{k l}+\frac{E}{2(1+v)}\left(\delta_{i k} \delta_{j l}+\delta_{i l} \delta_{j k}\right) \\
E_{i j k l}^{-1} & =-\frac{v}{E} \delta_{i j} \delta_{k l}+\frac{1+v}{2 E}\left(\delta_{i k} \delta_{j l}+\delta_{i l} \delta_{j k}\right)
\end{array}\right\}
$$

ここで， $\delta_{i j}$ はKroneckerのデルタ，つまり， $i=j$ のとき， $\delta_{i j}=1, i \neq j$ のとき, $\delta_{i j}=0$ である.

塑性ひずみ速度の定式化にあたり，等方・移動硬化を有する次式の降伏面（以下，正規降伏面と呼ぶ）を仮定 する.

$$
f(\hat{\boldsymbol{\sigma}})=F(H)
$$

ここで,

$$
\hat{\boldsymbol{\sigma}} \equiv \boldsymbol{\sigma}-\boldsymbol{\alpha}
$$

$\boldsymbol{\alpha}$ は移動硬化変数（背応力）であり， $F$ は等方硬軟化変数 $H$ の関数で, 硬化関数と呼ばれる. なお, $f$ は $\hat{\boldsymbol{\sigma}}$ の一 次の同次関数で，任意のスカラー $s$ に対して $f(|s| \hat{\boldsymbol{\sigma}})=|s| f(\hat{\boldsymbol{\sigma}})$ を満たすとする.

下負荷面モデルでは, 応力が正規降伏面に近づくにつれて塑性変形が発達し, 正規降伏面に達すると古典弾塑 性構成式が成り立つと仮定する，そこで，現応力点を通り正規降伏面に相似な下負荷面を考え，その正規降伏面 への接近の度合いとして正規降伏比 $R(0 \leq R \leq 1)$ を導入する. さらに正規降伏面と下負荷面の相似中心 $\mathbf{s}$ を導 入して, 下負荷面は次式で表される.

$$
f(\overline{\boldsymbol{\sigma}})=R F(H)
$$

ここで,

$$
\overline{\boldsymbol{\sigma}} \equiv \boldsymbol{\sigma}-\overline{\boldsymbol{\alpha}}
$$




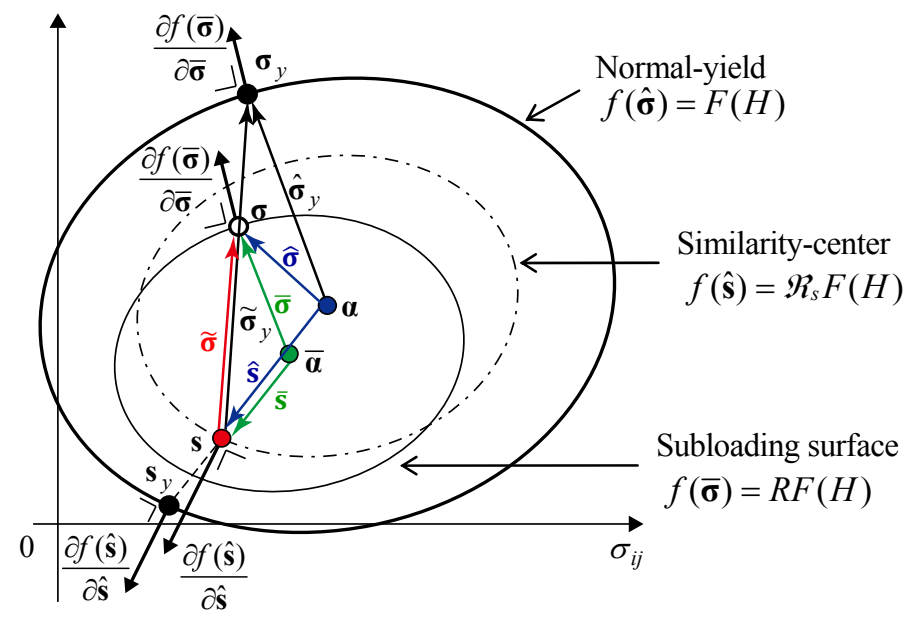

Fig. 1 Normal-yielding, subloading and similarity-center surfaces.

式(5)を時間微分して，次式を得る.

$$
\frac{\partial f(\overline{\boldsymbol{\sigma}})}{\partial \overline{\boldsymbol{\sigma}}}: \stackrel{\circ}{\boldsymbol{\sigma}}-\frac{\partial f(\overline{\boldsymbol{\sigma}})}{\partial \overline{\boldsymbol{\sigma}}}: \stackrel{\circ}{\boldsymbol{\alpha}}=R F^{\prime} \stackrel{\bullet}{H}+\stackrel{\bullet}{R} F
$$

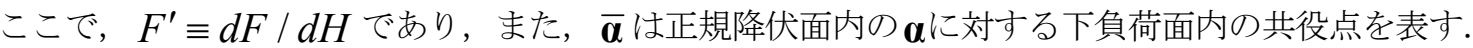

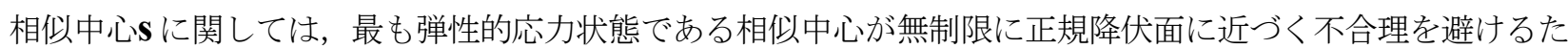
め，相似中心を通り背応力 $\boldsymbol{\alpha}$ に関して正規降伏面に相似な次式の相似中心面を導入する.

$$
f(\hat{\mathbf{s}})=\Re_{S} F(H)
$$

ここで,

$$
\hat{\mathbf{s}} \equiv \mathbf{s}-\boldsymbol{\alpha}
$$

相似中心降伏比 $\Re_{s}\left(0 \leq \Re_{s}<1\right)$ は，相似中心の降伏面一の接近の度合いを表す. 図 1 に，正規降伏面，下負荷面 および相似中心面の関係を示寸。ここに，相似中心発展則を次式で与える.

$$
\stackrel{\circ}{\mathbf{s}}=c\left\|\mathbf{d}^{p}\right\|\left(\frac{\overline{\boldsymbol{\sigma}}}{R}-\frac{\hat{\mathbf{s}}}{\chi}\right)+\stackrel{\circ}{\chi}+\frac{\dot{F}}{F} \hat{\mathbf{s}}
$$

ここで, $c$ および $\chi(<1)$ は材料定数であり, 後者は $\Re_{S}$ の最大值を示す.

正規降伏比 $R$ の発展則を次式で与える.

$$
\dot{R}=U(R)\left\|\mathbf{d}^{p}\right\|=u \cot \left(\frac{\pi}{2} \frac{\left\langle R-R_{e}\right\rangle}{1-R_{e}}\right)\left\|\mathbf{d}^{p}\right\| \quad \text { for } \mathbf{d}^{p} \neq \mathbf{0}
$$

ここで, $u$ は材料関数, $R_{e}(<1)$ は弹性限における $R$ 值を表す材料定数, 〈〉は $\langle S\rangle=(S+|S|) / 2$ で定義される Macauley の括弧を表す. なお, $u$ に関しては, 再負荷特性改善のため次式のように拡張されている.

$$
u=\bar{u} \exp \left(u_{s} \Re_{s} S_{\sigma}\right)
$$


ここで， $\bar{u}$ およ゙ $u_{S}$ は材料定数である．なお，部分除荷後の再負荷過程あるいは逆負荷過程では，応力はそれ ぞれ相似中心の外側あるいは内側に存在するが， $S_{\sigma}$ は外側に存在する度合いを表す変数であり, 次式で定義さ れる.

$$
S_{\sigma}=\hat{\mathbf{n}}_{s}:\left(\tilde{\boldsymbol{\sigma}}^{\prime} /\left\|\tilde{\boldsymbol{\sigma}}^{\prime}\right\|\right) \quad\left(-1 \leq S_{\sigma} \leq 1\right)
$$

ここで， $\hat{\mathbf{n}}_{s}$ は相似中心面の正規化外向き法線である．また， $\left.\tilde{\boldsymbol{\sigma}} \equiv \boldsymbol{\sigma}-\mathbf{s} て ゙ あ り （ （ ~\right)^{\prime}$ は偏差成分を表す.

式(7)に式(10)，(11)および関連流動則を考慮すると，塑性ひずみ速度は次式で与えられる.

$$
\begin{aligned}
& \mathbf{d}^{p}=\frac{\overline{\mathbf{N}}: \stackrel{\boldsymbol{\sigma}}{\mathbf{\sigma}}^{p}}{M^{p}} \overline{\mathbf{N}} \\
& M^{p} \equiv \overline{\mathbf{N}}:\left[\frac{F^{\prime} h}{F} \hat{\boldsymbol{\sigma}}+\mathbf{a}+\frac{U(R)}{R} \tilde{\boldsymbol{\sigma}}+c(1-R)\left(\frac{\overline{\boldsymbol{\sigma}}}{R}-\frac{\hat{\mathbf{s}}}{\chi}\right)\right]
\end{aligned}
$$

ここで， $\overline{\mathbf{N}}$ は下負荷面の正規化外向き法線，つまり

$$
\overline{\mathbf{N}} \equiv \frac{\partial f(\overline{\boldsymbol{\sigma}})}{\partial \overline{\boldsymbol{\sigma}}} /\left\|\frac{\partial f(\overline{\boldsymbol{\sigma}})}{\partial \overline{\boldsymbol{\sigma}}}\right\|
$$

である．また， $h \equiv \dot{H} / \lambda ， \mathbf{a} \equiv \stackrel{\boldsymbol{\sigma}}{/} / \lambda$ と定義する. 式(1)および式(14)より，ひずみ速度一応力速度関係およびそ の逆関係が次式のように得られる.

$$
\begin{aligned}
& \mathbf{d}=\mathbf{E}^{-1}: \stackrel{\circ}{\boldsymbol{\sigma}}+\frac{\overline{\mathbf{N}}: \stackrel{\circ}{\boldsymbol{\sigma}^{p}}}{M^{p}} \overline{\mathbf{N}} \\
& \stackrel{\circ}{\boldsymbol{\sigma}}=\mathbf{E}: \mathbf{d}-\frac{\overline{\mathbf{N}}: \mathbf{E}: \mathbf{d}}{M^{p}+\overline{\mathbf{N}}: \mathbf{E}: \overline{\mathbf{N}}} \mathbf{E}: \overline{\mathbf{N}}
\end{aligned}
$$

\section{$2 \cdot 2$ 金属の材料関数および繰返し等方硬化鈍化導入のための拡張}

金属に対してMises 降伏面を採用し，また，等方硬化変数 $H$ として相当塑性ひずみ $\varepsilon^{e q p}$ を採用して，次の正規 降伏面を仮定する.

$$
f(\boldsymbol{\sigma})=\sqrt{\frac{3}{2}}\left\|\boldsymbol{\sigma}^{\prime}\right\|=F\left(\varepsilon^{e q p}\right)
$$

ここで,

$$
\varepsilon^{e q p} \equiv \int \sqrt{\frac{2}{3}}\left\|\mathbf{d}^{p}\right\| d t
$$

硬化関数 $F$ の具体形は， $F_{0}, h_{1}, h_{2}$ を材料定数として次式で与える.

$$
F\left(\varepsilon^{e q p}\right)=F_{0}\left\{1+h_{1}\left[1-\exp \left(-h_{2} \varepsilon^{e q p}\right)\right]\right\}
$$


また，移動硬化変数 $\boldsymbol{\alpha}$ の発展則は， $a_{\alpha}$ および $r_{\alpha}$ を材料定数として次式で与える.

$$
\stackrel{\circ}{\boldsymbol{\alpha}}=a_{\alpha}\left(r_{\alpha} F \overline{\mathbf{N}}-\sqrt{\frac{2}{3}} \boldsymbol{\alpha}\right)\left\|\mathbf{d}^{p}\right\|
$$

金属材料で観察される繰返し等方硬化鈍化現象に対して，下負荷面の概念に基づいた定式化がなされている. 塑性ひずみ $\boldsymbol{\varepsilon}^{p}$ が次式で表される正規等方硬化面の面内にあるときには等方硬化の進展が鈍化すると仮定する (Chaboche, et al., 1979).

$$
\begin{gathered}
\breve{f}\left(\breve{\boldsymbol{\varepsilon}}^{p}\right)=K \\
\breve{\boldsymbol{\varepsilon}}^{p} \equiv \boldsymbol{\varepsilon}^{p}-\breve{\boldsymbol{\alpha}}
\end{gathered}
$$

ここで，Kおよび $K$ は正規等方硬化面の大きさおよび中心を表す．なお，応力空間で定義される変数と混同する ことを避けるため, ひずみ空間で定義される变数には( 一)を付与していることに注意されたい. いま, 現塑性ひ ずみ点 $\boldsymbol{\varepsilon}^{p}$ を通り正規等方硬化面に相似な下等方硬化面を考え，次式で与える(Hashiguchi et. al., 2012).

$$
\breve{f}\left(\breve{\boldsymbol{\varepsilon}}^{p}\right)=\breve{R} K
$$

ここで， $\breve{R}(0 \leq \breve{R} \leq 1)$ は正規等方硬化面に対する下等方硬化面の大きさの比であり， $\breve{R}$ を用いて $K$ 膨張速 度および $\breve{a}$ の移動速度を次式で与える.

$$
\begin{aligned}
& \dot{K}=C \breve{R}^{\zeta}\left\langle\frac{\partial \breve{f}\left(\breve{\boldsymbol{\varepsilon}}^{p}\right)}{\partial \breve{\boldsymbol{\varepsilon}}^{p}}: \mathbf{d}^{p}\right\rangle=C \breve{R}^{\zeta}\left\langle\frac{\partial \breve{f}\left(\breve{\boldsymbol{\varepsilon}}^{p}\right)}{\partial \breve{\boldsymbol{\varepsilon}}^{p}}: \overline{\mathbf{N}}\right\rangle\left\|\mathbf{d}^{p}\right\| \\
& \dot{\boldsymbol{\alpha}}=(1-C) \breve{R}^{\zeta}\left\langle\breve{\mathbf{N}}: \mathbf{d}^{p}\right\rangle \breve{\mathbf{N}}=(1-C) \breve{R}^{\zeta}\langle\breve{\mathbf{N}}: \overline{\mathbf{N}}\rangle\left\|\mathbf{d}^{p}\right\| \breve{\mathbf{N}}
\end{aligned}
$$

ここで， $\breve{\mathbf{N}}$ は下等方硬化面の正規化外向き法線，つまり

$$
\breve{\mathbf{N}} \equiv \frac{\partial \breve{f}\left(\breve{\boldsymbol{\varepsilon}}^{p}\right)}{\partial \breve{\boldsymbol{\varepsilon}}^{p}} /\left\|\frac{\partial \breve{f}\left(\breve{\boldsymbol{\varepsilon}}^{p}\right)}{\partial \breve{\boldsymbol{\varepsilon}}^{p}}\right\|
$$

$C(0 \leq C \leq 1)$ および $\zeta$ は材料定数である. また，等方硬化の進展に対しては，vを材料定数として次式の等方 硬化則を仮定する.

$$
\dot{\varepsilon}^{e q p}=\sqrt{\frac{2}{3}} \breve{R}^{v}\left\langle\breve{\mathbf{N}}: \mathbf{d}^{p}\right\rangle=\sqrt{\frac{2}{3}} \breve{R}^{v}\langle\breve{\mathbf{N}}: \overline{\mathbf{N}}\rangle\left\|\mathbf{d}^{p}\right\|
$$

\section{3. 繰返し負荷試験}

第 2 章に述べた下負荷面モデルを繰返し軟化を示す金属に適用するため, アメリカ石油協会（American Petroleum Institute) で規定されているシームレス鋼管P110(API Spec 5CT，2005)を供試して，繰返し負荷試験を 実施した。供試体は, 外径 $244.8 \mathrm{~mm}$, 肉厚 $13.84 \mathrm{~mm}$ の素管の管軸方向から採取した平行部直径 $10 \mathrm{~mm}$ の丸棒 試験片（ゲージ長さ $10 \mathrm{~mm}$ ) である. 試験機には, MTS 社製電気一油圧サーボ式疲労試験機 (最大軸荷重 $250 \mathrm{kN}$ ) を使用した。 
以上により，単軸負荷挙動を対象に，軸ひずみ速度 0.001 /s で，ひずみ制御による単調負荷試験および繰返し 負荷試験を行った．単純引張試験は試験片が破断するまで行い，また，単純圧縮試験は軸ひずみが一 0.03 に達す るまで実施した，次に，繰返し負荷試験として定ひずみ振幅繰返し負荷試験およびひずみ制御ラチェット試験を 実施した。定ひずみ振幅繰返し試験では，軸ひずみ振幅 $\pm 0.004 ， \pm 0.006, \pm 0.01$ および \pm 0.015 の 4 水準におい て, 繰返し数 20 回とした.また, ひずみ制御ラチェット試験では, 引張および圧縮状態を対象に, 所定のひずみ まで負荷し, その後, 荷重ゼロまで除荷して再負荷する応力片振り繰返し試験を実施した. なお, 繰返し数を 6 回とし，各繰返しでは，軸ひずみ $0.002 ， 0.006 ， 0.01 ， 0.014 ， 0.018$ および 0.022 (圧縮状態においては, マイ ナス）において，除荷に転じるように制御した。

単純引張および単純圧縮試験で得られた応力ーひずみ関係を図 2 に示す．ただし，本図では引張および圧縮の 応力・ひずみを共に正の值として示している．引張および圧縮試験での $0.2 \%$ 而力はそれぞれ $863 \mathrm{MPa}$ および $900 \mathrm{MPa}$ であり，若干の初期強度異方性が見られた。

繰返し負荷試験結果の一例として, 軸ひずみ振幅 \pm 0.006 の定ひずみ振幅繰返し試験および引張のひずみ制御ラ チェット試験の応力ーひずみ関係を図3に示す. 定ひずみ振幅繰返し試験では, 応力振幅が繰返しとともに減少 する繰返し軟化現象が現れている．この現象は他の軸ひずみ振幅の試験でも確認された．また，ひずみ制御ラ チェット試験では, 繰返し負荷とともに硬化する現象が現れている.さらに, 除荷一再負荷時にヒステリシスルー プを描き，全ひずみが大きくなるにしたがってループは大きくなっている.

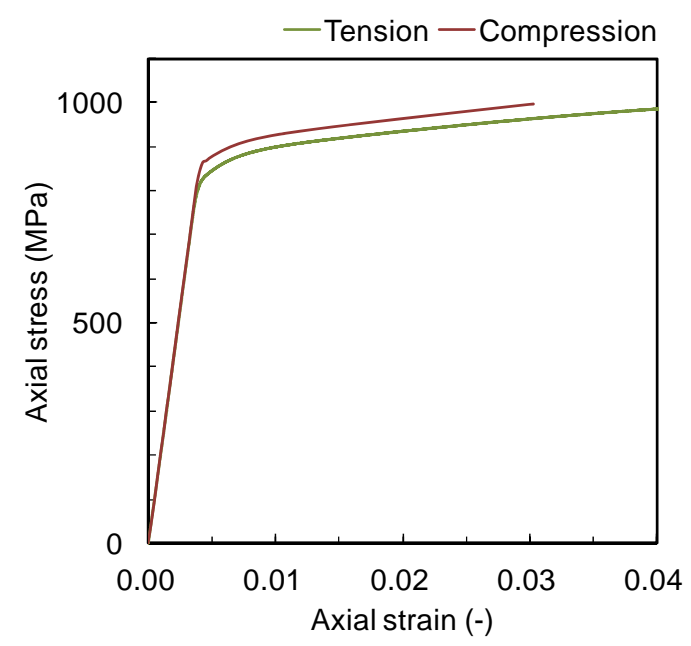

Fig. 2 Stress-strain relations in tension and compression.

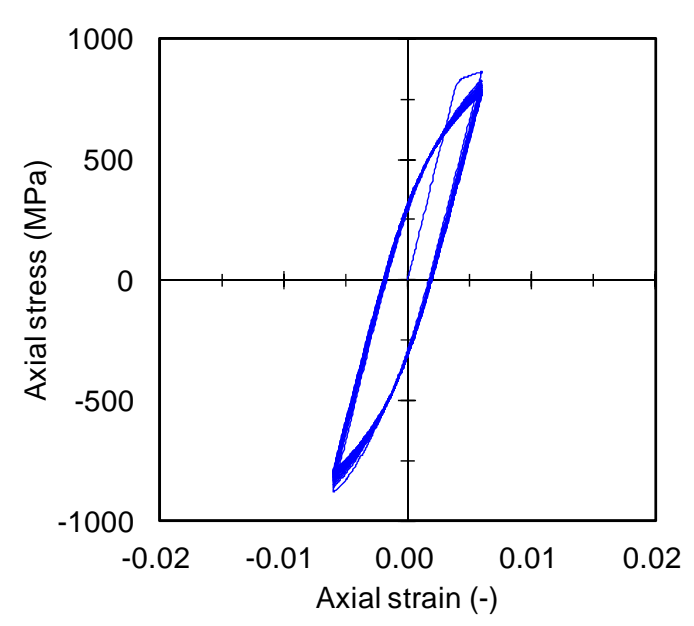

(a) Cyclic loading under the constant strain amplitude of \pm 0.006 .

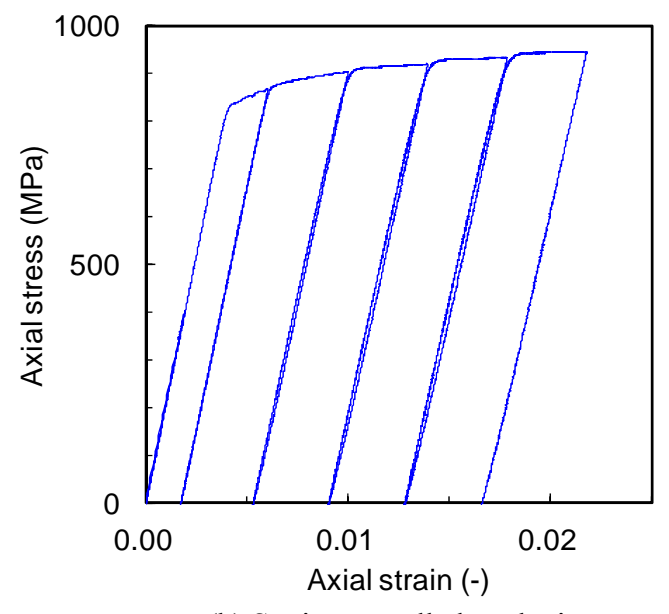

(b) Strain-controlled ratcheting

Fig. 3 Cyclic stress-strain relations. 


\section{4. 下負荷面モデルにおける材料関数の拡張}

\section{4・1＼cjkstart既往の下負荷面モデルの繰返し負荷試験への適用}

繰返し負荷試験で得られた応力ーひずみ関係を再現するため, 第2章で述べた下負荷面モデルを適用した. 計算 結果の一例として, 軸ひずみ振幅 0 0.006での定ひずみ振幅繰返し試験および引張荷重でのひずみ制御ラチェット 試験について実測データとの比較を図4に示寸.

図4(a)の定ひずみ振幅繰返し試験に関しては，1.5サイクル目まで，すなわち1回目の引張から2回目の引張まで の応力ーひずみ関係と，10サイクル目および20サイクル目の応力ーひずみ関係を比較している. 初期負荷時の挙 動は実測とかい離しているのに対し，後続負荷時の挙動は良く一致している．材料パラメータ值を変更して初期 負荷時の挙動を実測と一致させると，逆に後続負荷時の挙動が実測とかい離する結果となった。一方，図4(b)の ひずみ制御ラチェット試験では，初期負荷時の挙動は実測と良く一致しているものの，後続負荷においては，計 算曲線にヒステリシスループの幅は見られず，実測曲線を十分表現されていない，なお，ヒステリシスループを 再現するように材料パラメータ值を変更すると，初期負荷時の挙動の予測精度が低下した。 これらの結果から， 既往の下負荷面モデルの定式化では，初期負荷時と後続負荷時の挙動をともに高精度に表現し得るように材料パ ラメータ值を決定することが困難であることが判明した。

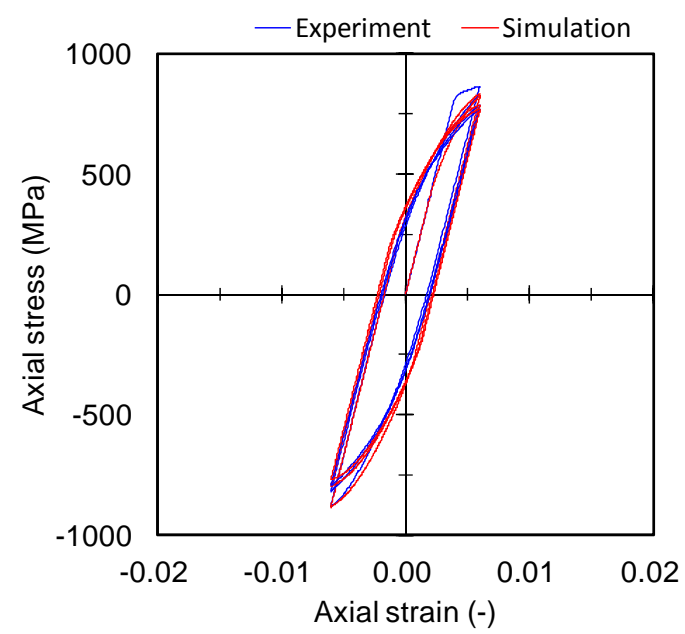

(a) Cyclic loading under the constant strain amplitude of \pm 0.006 .

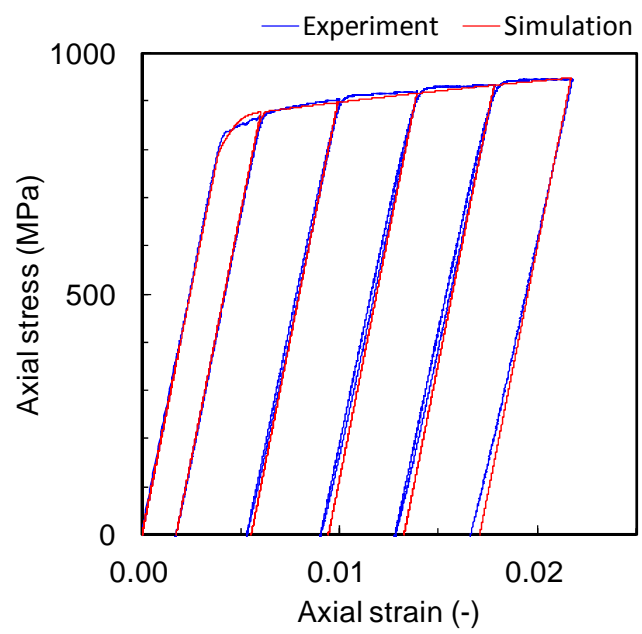

(b) Strain-controlled ratcheting

Fig. 4 Comparison of stress-strain relation between experiment and simulation by the existing subloading surface model.

\section{$4 \cdot 2$ 弾性限発展則の導入}

定ひずみ振幅繰返し試験の応力一ひずみ関係において，後続負荷では弾性領域から弾塑性遷移領域への移行が 初期負荷に比べて早期に生じている．また，ひずみ制御ラチェット試験では，後続負荷においては，変形の進行 に伴いより低い応力レベルで弾性領域から弾塑性遷移領域に移行することによりヒステリシスループが発現して いると考えられる.

上述の観点から，以下に，既往の下負荷面モデルの定式化の改良を行う。正規降伏比の発展則における弾性限 $R_{e}$ がひずみの蓄積とともに低下寸ると仮定し，弾性限の発展則を相当塑性ひずみの関数として次式で与える.

$$
R_{e}=R_{e \text { Min }}+\left(R_{e 0}-R_{e \text { Min }}\right) \exp \left(-\eta \varepsilon^{e q p}\right)
$$

ここで, $R_{e 0}$ は $R_{e}$ の初期值, $R_{e \mathrm{Min}}$ は $R_{e}$ の下限值, $\eta$ は材料定数である. 図 5 示すように, $R_{e}$ は初期值 $R_{e 0}$ から $\varepsilon^{e q p}$ の増加とともに指数関数的に減少し, $R_{e \mathrm{Min}}$ に漸近する.

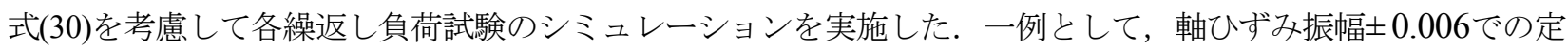
ひずみ振幅繰返し試験, および引張のひずみ制御ラチェット試験についての結果を図6に示す. 初期負荷と後続負 荷での挙動や，ひずみ制御ラチェット試験でのヒステリシスループの表現が改善されることがわかる．他の繰返 


\section{し負荷試験についても，同様に高精度な計算結果が得られた。}

しかしながら，上記のシミュレーションでは各繰返し負荷試験によって材料パラメータ值を変更している．具 体的には, 式(12)の $\bar{u}$ および式(10)の $c$ の值を各繰返し負荷試験によって変更し，他の材料パラメータは同一の 值を用いた．例えば，図 6 の定ひずみ振幅繰返し試験では $(\bar{u}, c)=(110,130)$, ひずみ制御ラチェット試験では $(\bar{u}, c)=(350,300)$ とした．比較のため, $\quad(\bar{u}, c)=(110,130)$ を使用して，軸ひずみ振幅 \pm 0.01 での定ひずみ振

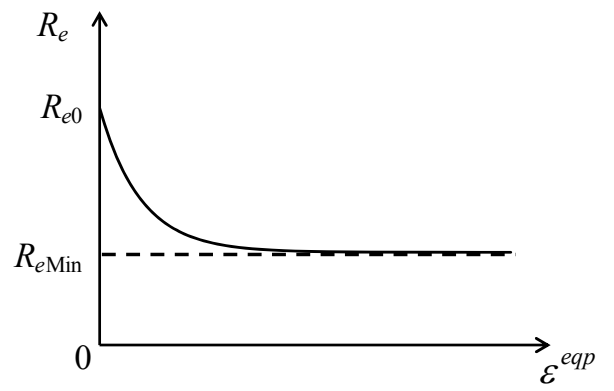

Fig. 5 Evolution rule of the elastic limit of the normal-yield ratio as a function of equivalent plastic strain .

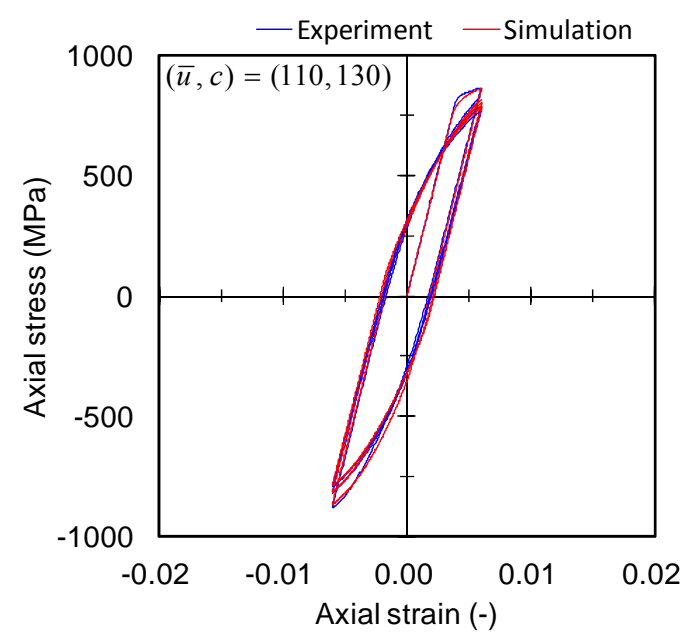

(a) Cyclic loading under the constant strain amplitude of \pm 0.006

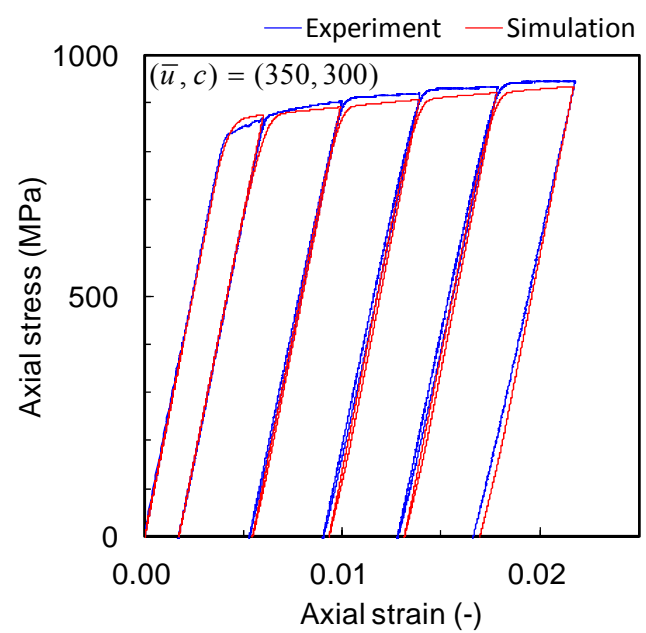

(b) Strain-controlled ratcheting

Fig. 6 Simulated results by the subloading surface model extended incorporating evolution rules of the elastic limit of the normal-yield ratio.

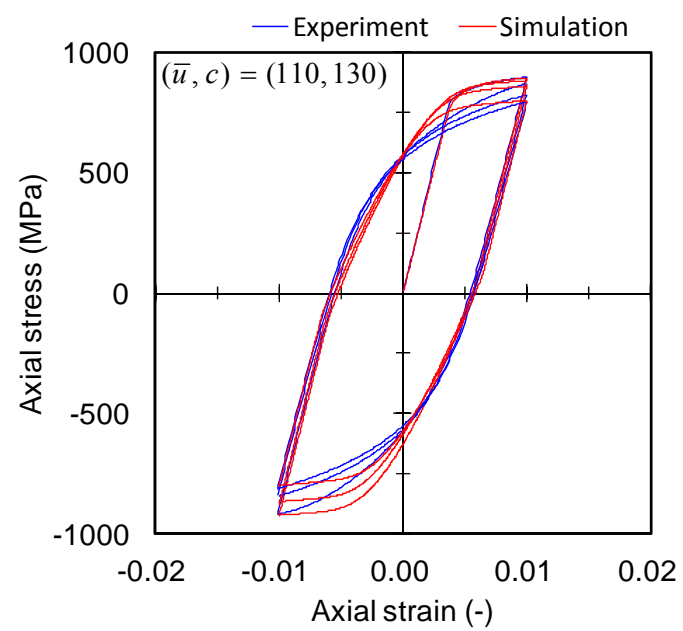

(a) Cyclic loading under the constant strain amplitude of \pm 0.01

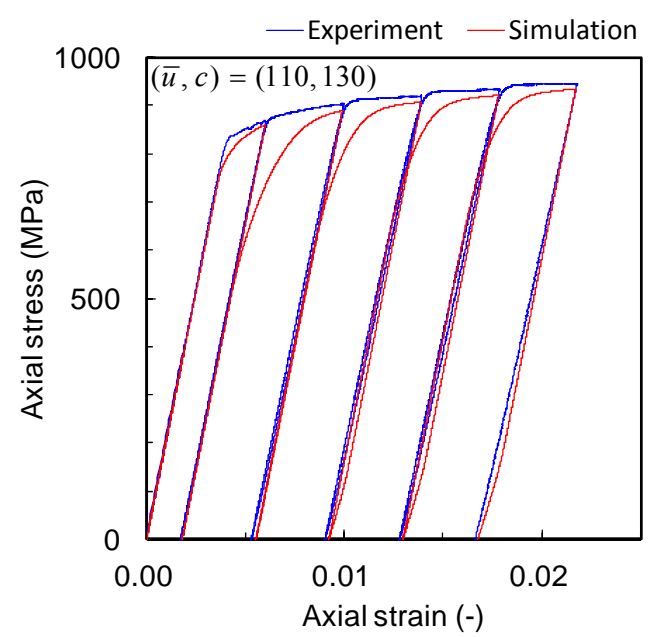

(b) Strain-controlled ratcheting test

Fig. 7 Simulated results by using same material constants as the simulation shown in Fig. 6(a). 
幅繰返し試験および引張荷重でのひずみ制御ラチェット試験のシミュレーションを実施した。軸ひずみ振幅 \pm 0.01 での定ひずみ振幅繰返し試験では $(\bar{u}, c)=(90,20)$ とすれば高精度な計算結果を得ることができたが, $(\bar{u}, c)=(110,130)$ とすると, 図 7(a)に示すように弾塑性遷移領域での挙動に実測データと大きな差異が現れた. ひずみ制御ラチェット試験についても $(\bar{u}, c)=(110,130)$ とすると, 図 7(b)のように再負荷曲線の先行負荷曲線 への復帰が緩慢になる挙動が現れた。 寸なわち，このままでは，全ての材料パラメータに試験条件によらない同 一の值を用いて各試験結果を高精度に予測することは困難であることが判明した.

\section{$4 \cdot 3$ 正規降伏比発展則と相似中心発展則の改良}

同一材料に対しては，試験条件によって材料パラメータ值を変更することなく，同一の值で変形挙動を予測す ることが求められる. しかしながら, 前節で提案した弾性限発展則を考慮するだけでは, 同一の材料パラメータ 值の組を用いると, 定ひずみ振幅繰返し試験においては, 弾塑性遷移領域での曲率が軸ひずみ振幅の大きさによっ て異なる点を再現できない，また，ひずみ制御ラチェット試験においては，再負荷曲線の先行負荷曲線への復帰 が緩慢になる等の不具合が発生した。 これらの欠点を解消するため, さらに以下のような改良を行った.

まず，正規降伏比発展則に関係する式(12)の材料パラメータ $\bar{u}$ を定数ではなく, 次式のような正規等方硬化面 の大きさKの関数として与える.

$$
\bar{u}=u_{0}\left[1-u_{1}\left\{1-\exp \left(-u_{2}\left(K-K_{0}\right)\right)\right\}\right]
$$

ここで， $K_{0}$ は $K$ 初期值， $u_{0}, u_{1}$ および $u_{2}$ は材料定数である. 図8に示寸ように, $\bar{u}$ は初期值 $K_{0}$ での值 $u_{0}$ から $K$ の増加とともに指数関数的に減少し, $u_{0}\left(1-u_{1}\right)$ に漸近する. 同様に, 式(10)の相似中心発展則の材料パラメータ

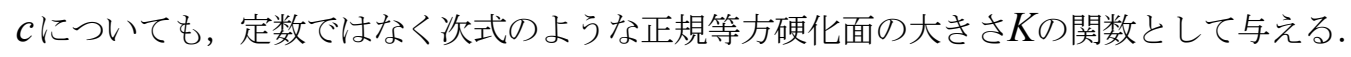

$$
c=c_{0}\left[1-c_{1}\left\{1-\exp \left(-c_{2}\left(K-K_{0}\right)\right)\right\}\right]
$$

ここで， $c_{0}, c_{1}$ および $c_{2}$ は材料定数である. 図8に示すように, $c$ は初期值 $K_{0}$ における值 $c_{0}$ から $K$ の増加ととも に指数関数的に減少し, $c_{0}\left(1-c_{1}\right)$ に漸近する. 式(31)および式(32)により, 軸ひずみ振幅による弾塑性遷移領域 での曲率の変化が改善される.

さらに，正規降伏比発展則に関係する式(12)を次式のように与える.

$$
u=\bar{u} \exp \left[\left(u_{r}+u_{s} S_{\sigma}\right) \Re_{s}\right]
$$

ここで, $u_{r}$ は材料定数である. 式(33)により, 再負荷曲線の先行負荷曲線により速やかに復帰するよう改善され る.

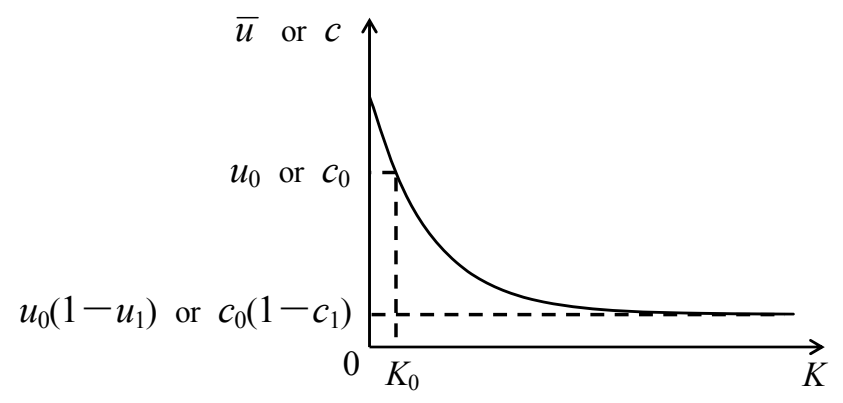

Fig. 8 Material parameters described as a function of the size of the normal-isotropic hardening surface in the evolution rule of the normal-yield ratio or the translation rule of the similarity-center . 


\section{5. 考察}

第 4 章で述べた改良モデルにより繰返し負荷試験のシミュレーションを行い，実測データと比較することによ りその妥当性を検証した．材料パラメータ值は表 1 のよう選び，全ての試験に対して同一の值を使用した.

ヤング率およびポアソン比については，一般的な鋼材の值を用いた．また，本研究で使用したシームレス鋼管 では, 図 3 のように繰返し軟化挙動を示寸. 本現象を表現するため, 式(21)の硬化関数において $h_{1}=-0.15$ を与 えることとした．移動硬化に関する材料パラメータ值は，ひずみ制御ラチェット試験の結果をもとに決定した. なお, 図 2 で示寸ように, 引張側と圧縮側で初期強度異方性が見られたため, 移動硬化変数の初期值として $\alpha_{11}=-15, \quad \alpha_{22}=\alpha_{33}=-\alpha_{11} / 2, \quad \alpha_{i j}=0(i \neq j)$ を与えた. ここに，添字 1 および $2 ， 3$ は，それぞれ負荷軸方向 およびその垂直方向に対応する.

式(30)の弾性限 $R_{e}$ については初期を 0.85 とし，ひずみの蓄積とともに 0.33 まで減少するとした．弾塑性遷移

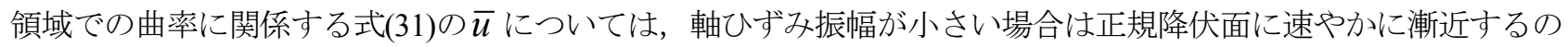
で $\bar{u}$ が大，逆に軸ひずみ振幅が大きい場合は正規降伏面に緩やかに漸近するので メータ值を決定した，式(32)の $c$ についても同様に，軸ひずみ範囲が小さい場合は $c$ が大きくなるように，軸ひ ずみ範囲が大きい場合には $c$ が小さくなるように材料パラメータ值を与えた. また, 式(31)および式(32) との関連 を考慮しながら，正規等方硬化面の大きさ $K$ に関係する等方硬化鈍化についての材料パラメータ值を決定した. さらに，ひずみ制御ラチェット試験において再負荷曲線が先行負荷曲線へ速やかに復帰するように式(33)の $u_{r}$ を 決定した.

定ひずみ振幅繰返し試験の計算結果と実測データとの比較を図 9 に示す.ここでは, 1.5 周期までの応力ーひず み関係と，10 サイクル目および 20 サイクル目の応力ーひずみ関係を比較している.いずれの軸ひずみ振幅の試 験に対しても, 応力ーひずみ関係が高精度に再現されていることがわかる. 軸ひずみ振幅による弾塑性遷移領域 での曲率の違いも表現できている. また, 図 10 は各サイクルでの引張および圧縮の最大応力を示したものである. 本モデルにより，実測值の繰返し軟化現象が高精度で表現されている.

Table 1 Material constants used in simulations by the subloading model extended in the present paper.

\begin{tabular}{|c|c|c|c|c|c|c|c|c|c|c|c|}
\hline \multicolumn{2}{|c|}{ Elastic property } & \multicolumn{3}{c|}{ Isotropic hardening } & \multicolumn{3}{c|}{ Kinematic hardening } & \multicolumn{4}{c|}{ Translation of similarity-center } \\
\hline$E$ & $v$ & $F_{0}$ & $h_{1}$ & $h_{2}$ & $a_{\alpha}$ & $r_{\alpha}$ & $\alpha_{11}$ & $c_{0}$ & $c_{1}$ & $c_{2}$ & $\chi$ \\
\hline 205000 & 0.3 & 885 & -0.15 & 15 & 27 & 0.22 & -15 & 200 & 0.8 & 1500 & 0.7 \\
\hline \hline \multicolumn{8}{|c|}{ Evolution of normal-yield ratio } & \multicolumn{1}{c|}{ Stagnation of isotropic hardening } \\
\hline$u_{0}$ & $u_{1}$ & $u_{2}$ & $u_{\mathrm{r}}$ & $u_{\mathrm{s}}$ & $R_{e}$ & $R_{e \text { Min }}$ & $\eta$ & $C$ & $\zeta$ & $v$ & $K_{0}$ \\
\hline 250 & 0.75 & 1000 & 2.5 & 3.5 & 0.85 & 0.33 & 1200 & 0.5 & 20 & 0.001 & 0.001 \\
\hline
\end{tabular}

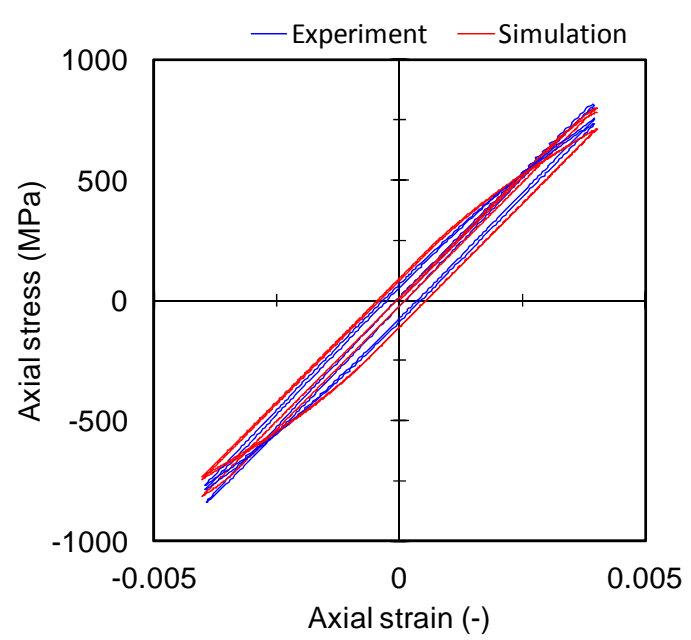

(a) Constant strain amplitude of \pm 0.004

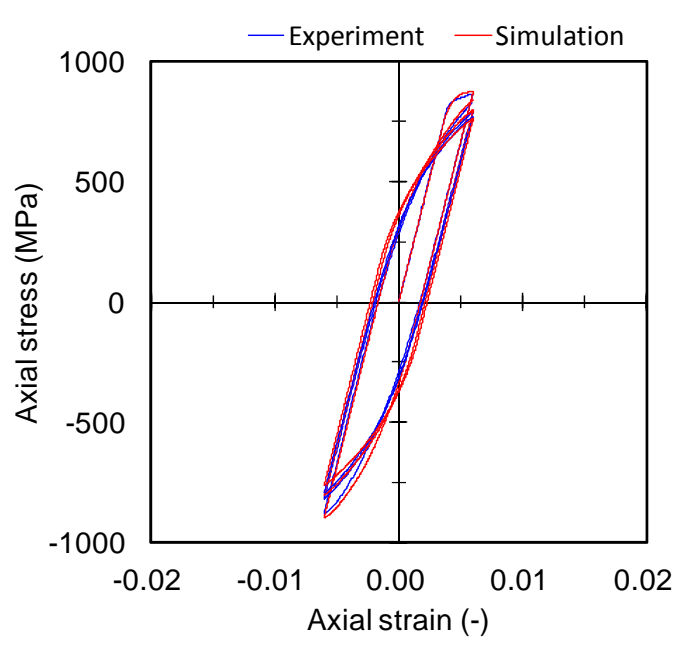

(b) Constant strain amplitude of \pm 0.006

Fig. 9 Comparison of stress -strain relation between experiment and simulation by the subloading model extended in the present paper for cyclic loading under constant strain. 


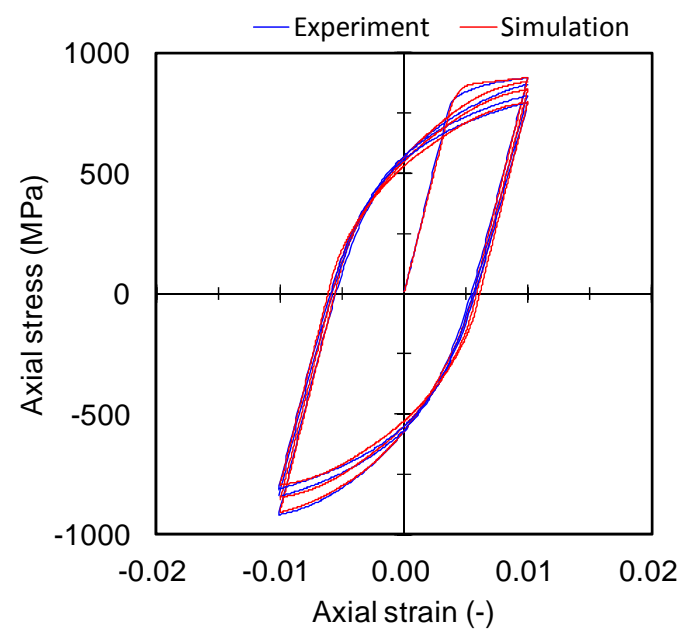

(c) Constant strain amplitude of \pm 0.01

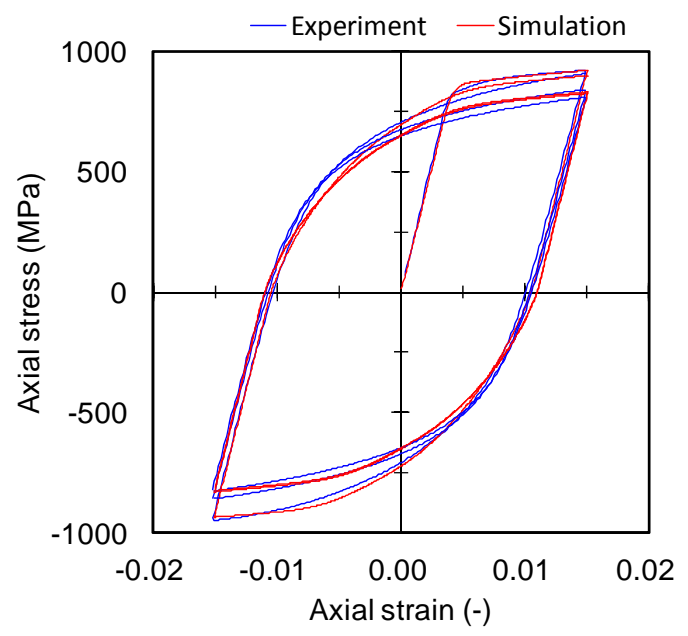

(d) Constant strain amplitude of \pm 0.015

Fig. 9 Continued.

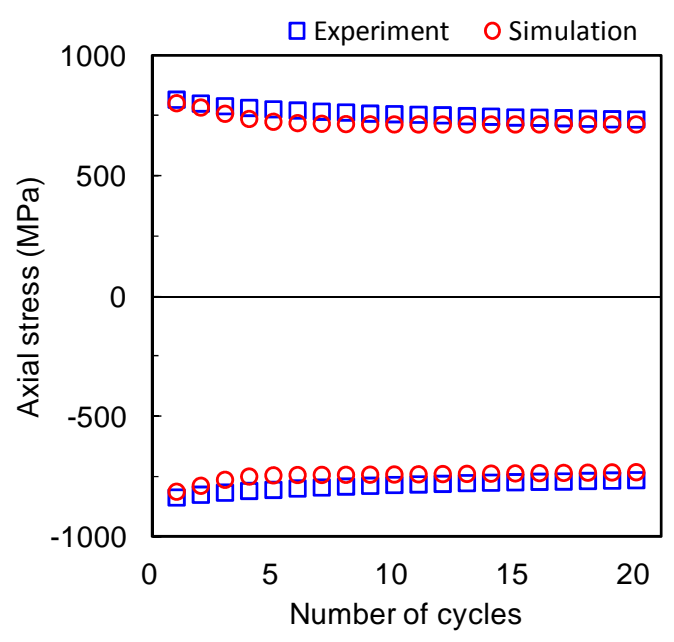

(a) Constant strain amplitude of \pm 0.004

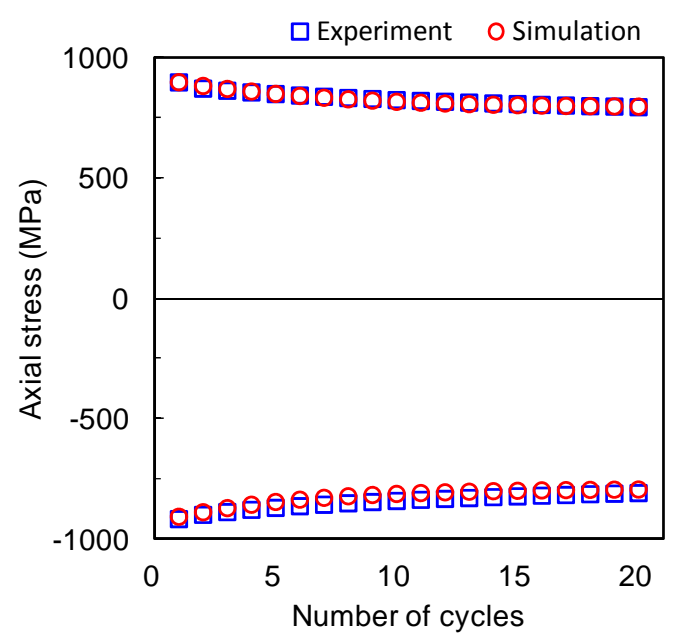

(c) Constant strain amplitude of \pm 0.01

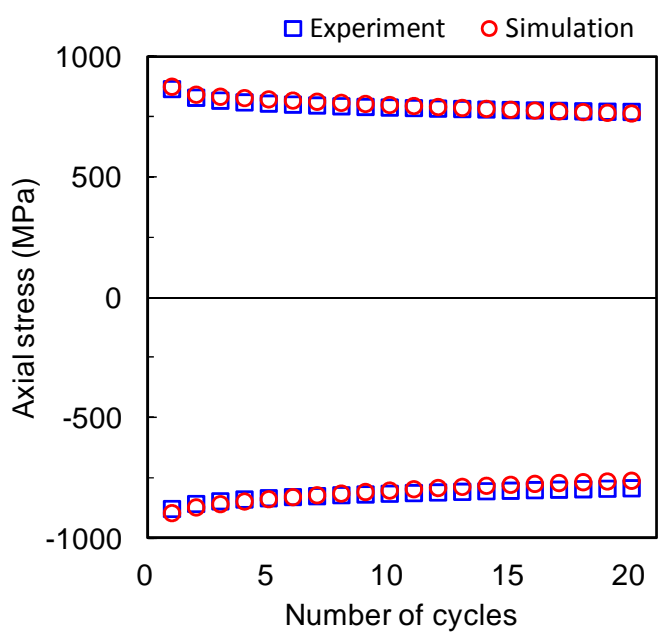

(b) Constant strain amplitude of \pm 0.006

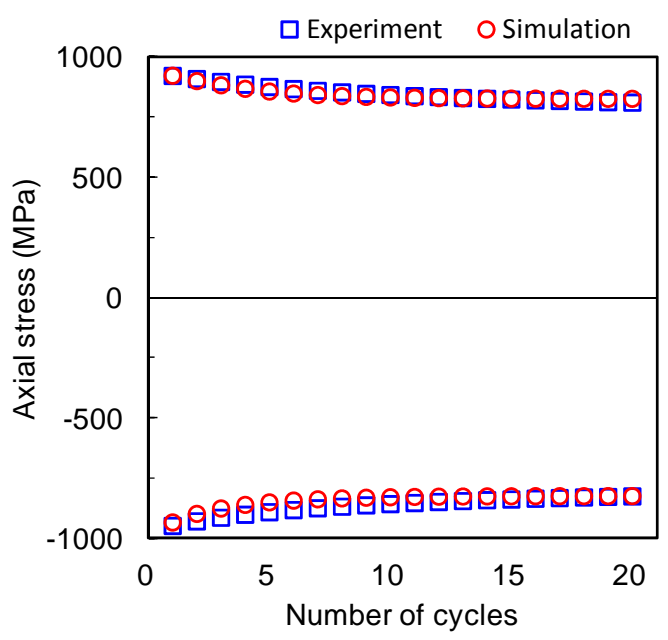

(d) Constant strain amplitude of \pm 0.015

Fig. 10 Change of maximum tensile and compression stress for cyclic loading under constant strain. 


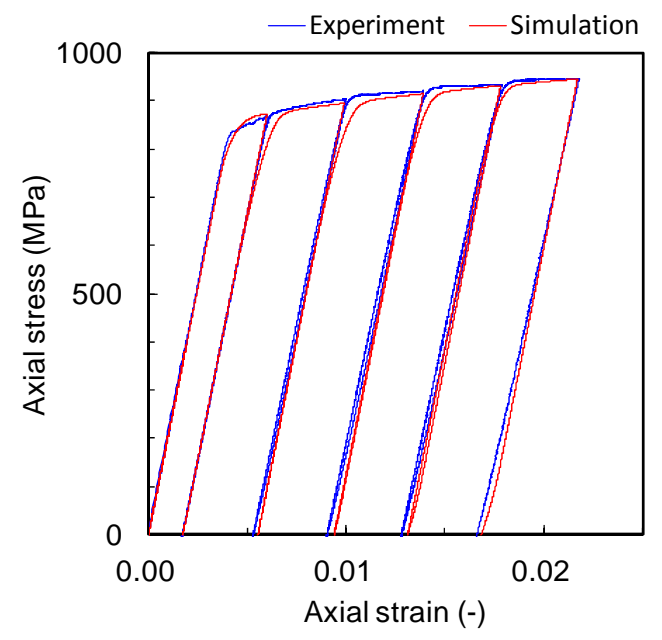

(a)Tension

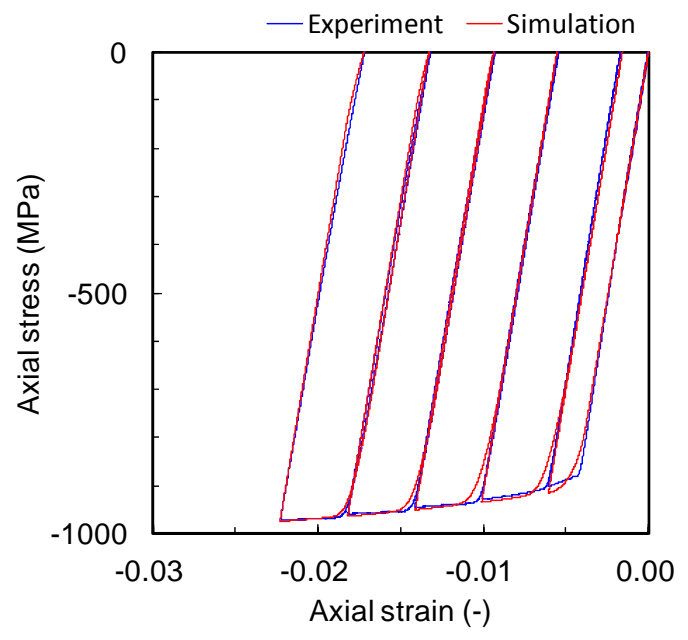

(b)Compression

Fig. 11 Comparison of stress-strain relation between experiment and simulation by the subloading model extended in the present paper for strain-controlled ratcheting test.

また，片振りのひずみ制御ラチェット試験の計算結果と実測データとの比較を図 11 に示す. 引張・圧縮いずれ においても，計算結果と実測結果に良い一致が見られる。硬化特性やヒステリシスループの形状が高精度に表わ されている.

以上のように，本研究で提案した拡張モデルにより，材料パラメータ值を試験条件によって变更することなく 繰返し負荷試験を高精度に再現し得ることが実証された。

\section{6. 結}

本報では，繰返し硬化のみならず繰返し軟化を示す金属を対象に，逆負荷・再負荷特性および繰返し負荷にお けるひずみの集積を高精度で表現し得るように，下負荷面モデルに含まれる材料パラメータを次のように拡張し た.

1) 正規降伏比の発展則における弾性限界に関する材料パラメータを, 相当塑性ひずみの増加に伴い指数関数的 に低下して下限值に漸近するように拡張した。

2) 正規降伏比の発展則における塑性ひずみ速度に対する比例係数を, 正規等方硬化面の大きさの増加に伴い指 数関数的に低下して下限值に漸近するように拡張した.

3) 相似中心の発展則における比例係数を, 正規等方硬化面の大きさの増加に伴い指数関数的に低下して下限值 に漸近するように拡張した。

4) 正規降伏比の発展則における塑性ひずみ速度に対する比例係数を, 再負荷曲線が先行負荷曲線へ速やかに復 帰するように拡張した。

下負荷面モデルの定式化のこれらの拡張により，繰返し軟化を示すシームレス鋼管材料を対象に行った単軸負荷 条件における定ひずみ振幅繰返し試験, および応力片振り試験, つまり力学的ラチェット試験結果を同一の材料 パラメータ值の組を用いて，高精度でシミュレーションし得ることが実証された。

\section{References}

American Petroleum Institute, API Specification 5CT/ISO 11960:2004, Specification for casing and tubing (2005).

Chaboche, J.L., Dang-Van, K. and Cordier, G., Modelization of the strain memory effect on the cyclic hardening of 316 stainless steel, Transactions of the 5th International Conference of SMiRT, Berlin, Division L., Paper No.L.11/3 (1979).

Dafalias, Y.F. and Popov, E.P., A model of nonlinearly hardening materials for complex loading, Acta Mechanica, Vol.23 (1975), pp.173-192. 
Hashiguchi, K., Constitutive equations of elastoplastic materials with elastic-plastic transition, Journal of Applied Mechanics, Vol.47 (1980), pp.266-272.

Hashiguchi, K., Subloading surface model in unconventional plasticity, International Journal of Solids and Structures, Vol.25 (1989), pp.917-945.

Hashiguchi, K., Ueno, M. and Ozaki, T., Elastoplastic model of metals with smooth elastic-plastic transition, Acta Mechanica, Vol. 223 (2012), pp.985-1013.

Hashiguchi, K., Elastoplasticity Theory, Springer (2013).

Iwan, W.D., On a class of models for yielding behavior of continuous and composite systems, Journal of Applied Mechanics, Vol.34 (1967), pp.612-617.

Krieg, R.D., A practical two surface plasticity theory, Journal of Applied Mechanics, Vol.42(1975), pp.641-646.

Mroz, Z., On the description of anisotropic workhardening, Journal of the Mechanics and Physics of Solids, Vol.15 (1967), pp.163-175.

Ohno, N. and Wang, J.D., Kinematic hardening rules with critical state of dynamic recovery, Part I:Formulation and basic features for ratcheting behavior, International Journal of Plasticity, Vol.9 (1993a), pp.375-390.

Ohno, N. and Wang, J.D., Kinematic hardening rules with critical state of dynamic recovery, Part II:Application to experiments of ratcheting behavior, International Journal of Plasticity, Vol.9 (1993b), pp.391-403.

Yoshida, F. and Uemori, T., Elastic-plastic behavior of steel sheets under in-plane cyclic tension-compression at large strain, International Journal of Plasticity, Vol.18(2002a), pp.633-659.

Yoshida, F. and Uemori, T., A large-strain cyclic plasticity describing the Bauschinger effect and workhardening stagnation, International Journal of Plasticity, Vol.18(2002b), pp.661-686.

Yoshida, F. and Uemori, T., A model of large-strain cyclic plasticity and its application to springback simulation, International Journal of Mechanical Sciences, Vol.45(2003), pp.1687-1702. 